
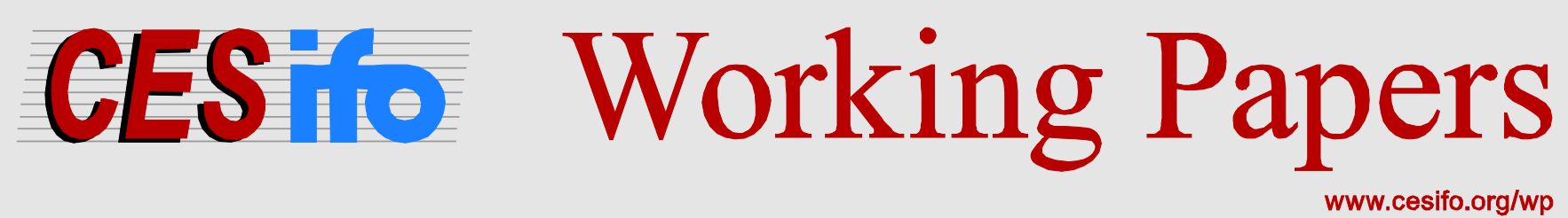

\title{
Export Market Exit, Financial Pressure and the Crisis
}

\author{
Holger Görg \\ Marina-Eliza Spaliara
}
CESIFO WORKING PAPER NO. 4363
CATEgory 8: TRAde Policy
August 2013
An electronic version of the paper may be downloaded
- from the SSRN website:
- from the RePEc website:
- from the CESifo website:
wWw.SSRN.com
www.RePEc.org
www.CESifo-group.org/wp

\section{CESifo}




\title{
Export Market Exit, Financial Pressure and the Crisis
}

\begin{abstract}
Using firm-level data for the UK, we investigate the link between firms' financial health, borrowing ratio and export exit, paying special attention to the recent financial crisis. Our results show that deterioration in the financial position of firms has increased the hazard of export exit during the crisis. We also find that the sensitivity of export exit to changes in firms' financial condition is higher during the crisis for those firms which face increases in loan spreads associated with the firm-specific interest rate.
\end{abstract}

JEL-Code: F100, L200, G300.

Keywords: financial pressure, firm exit, financial health, exports.

\author{
Holger Görg \\ Department of Economics \\ University of Kiel \\ Kiel / Germany \\ goerg@economics.uni-kiel.de
}

Marina-Eliza Spaliara

The Business School

University of Glasgow

Glasgow, G12 8QQ, Scotland

marina.spaliara@glasgow.ac.uk

August 2013 


\section{Introduction}

It has been well documented that trade declined very strongly as a result of the global financial crisis. For example, data in the World Trade Report 2012 show that average export growth was around 2 percent and -12 percent, respectively, in 2008 and 2009, and rebounded to +14 and +5 percent in 2010 and 2011, respectively (WTO (2012)). There have been various explanations for this trade collapse during the crisis, attributing it to strong fall in demand, a rise in protectionism, a domino effect because of global value chains, or restrictions in the access to finance for exporters (e.g., Baldwin and Evenett (2009), Chor and Manova (2012), Bricongne et al. (2012)).

Studies based on firm level data, such as Bricongne et al. (2012) generally conclude that most of the changes in export performance during the crisis are due to adjustments at the intensive margin, i.e., firms remain in their export markets but adjust the quantity of exports. Using data for French firms, they show that adjustment along the intensive margin accounted for 79 percent of the reduction in exports. Only 21 percent were due to adjustments at the extensive margin, i.e., through firms exiting from the export market.

Yet, adjustments along the external margin may have severe prolonged consequences for a country's export performance. Given that there are substantial sunk costs for (re-)entering export markets, firms exiting from the export market during the crisis are unlikely to re-enter again immediately after the negative shock disappears. Instead, it is likely that they will remain out of the export market. This is the phenomenon known as "Hysteresis" in exports (Baldwin (1990), Roberts and Tybout (1997)). ${ }^{1}$

If hysteresis is important (and empirical estimates of sunk costs of exporting, such as by Das et al. (2007) or Roberts and Tybout (1997) suggest that it is), then the exit triggered by the crisis may lead to a permanent reduction of the number of exporters in a country even after the crisis, i.e., export activity may become more concentrated among a smaller

\footnotetext{
${ }^{1}$ Impullitti et al. (2013) have recently embedded this idea in a general equilibrium model with heterogenous firms, where sunk costs of export entry and uncertainty about firm efficiency lead to hysteresis in firms export market participation.
} 
number of firms. This has potentially important policy implications for countries engaged in promoting export performance. The British government agency UK Trade \& Investment, for example, appears to have a strong focus on assisting firms to start exporting, i.e., increase the number of firms exporting rather than just the overall quantity of exports. ${ }^{2}$ In this case, firms dropping out of the export market should be of high concern to policy makers.

One important factor that might be held accountable for the decrease in the number of exporters is the access to external finance. As Amiti and Weinstein (2011) discuss, exports are highly dependent on access to finance, much more so than domestic operations of firms. Hence, a lack of finance may also cause firms to exit the market. Of course, corporate funding (or the lack thereof) has been a major concern for policy makers during the recent financial crisis. Serious concerns have been raised regarding the ability of banks to continue lending to firms after the massive losses that they incurred with the collapse of the financial market. Published evidence in the Quarterly Bulletin of the Bank of England (Bell and Young (2010)), reveals a substantial tightening in credit supply in Britain from mid-2007 and documents an increase in loan spreads on small and medium enterprises (SMEs). Thus, the cost of bank finance varies amongst firms leading to a heterogeneous firm-specific interest rate. A high borrowing ratio (or firm-specific interest rate) can be seen as evidence that the firm is charged a high external finance premium. Hence, during crisis periods the worsening of the balance sheet position of firms and the rise in debt servicing costs might be associated with higher chances of firm exit from the export market.

In this paper we focus on the extensive margin of exports and investigate firms' exit from the export market. Specifically, we investigate whether such exit has increased during the crisis, whether a firm's financial position can explain firm export exit, and whether the importance of financial health was more pronounced during the crisis. Moreover, we attempt to gauge the effect of the firm-specific interest rate on export exit during the crisis when loan spreads increased. The analysis is conducted using firm level data for the UK.

\footnotetext{
${ }^{2}$ See their information at http://www.ukti.gov.uk/de_de/export.html
} 
Our paper relates to a small but growing literature looking at the link between exports and finance, and the economic crisis in particular. Amiti and Weinstein (2011) present a comprehensive study of the link between firm's exports at the intensive margin and finance, focusing on the health of the bank providing access to credit. They look at the Japanese financial crisis from 1990 to 2010. Chor and Manova (2012) use product level data on US imports, investigating the role of credit conditions as the main culprit for reducing trade during the crisis. Due to the nature of their data they cannot look at intensive vs extensive margins at the firm level, however.

More closely related to our work is Bricongne et al. (2012) who also investigate the effects of the crisis, and focus on financial variables at the firm level. However, they strongly focus on the intensive margin in their empirical analysis, while we concentrate on the extensive margin. Studies by Askenazy et al. (2011) and Engel et al. (2013) also consider the role of financial indicators in exporting. The former study assesses theoretically and empirically the role of credit constrains in export market entry and exit, while the latter investigates the characteristics of companies deciding to participate in foreign markets and engage in exporting or foreign direct investment. ${ }^{3}$ Both studies use French firm-level data to look at the extensive margin but neither of them assess the impact of firm-specific interest rate on the hazards of export exit or consider the role of the recent financial crisis. ${ }^{4}$

Our novelty compared to the above studies is to look specifically at changes in export exit during the crisis, and the role financial health has played before and during the crisis. More importantly, we also consider the impact of the borrowing ratio on the hazard of export exit, indicating whether changes in the level of interest payments during the crisis might have affected firms' survival in the export market. To assess the role of the borrowing ratio in export exit, we rely on the literature that has looked at the link between firm-specific interest

\footnotetext{
${ }^{3}$ There is also a large and growing literature which suggests that financial health matters in exporting decisions (see for example Minetti and Zhu (2011), Berman and Hericourt (2010), Forlani (2010), Bellone et al. (2010), Muûls (2005) and Greenaway et al. (2007))

4 There are also a number of papers that have investigated firm exit from export markets in general (e.g., Girma et al. (2003) and Harris and Li (2011) for the UK, Ilmakunnas and Nurmi (2010) for Finland, Hiller et al. (2013) for Denmark, Wagner (2012) for Germany and Alvarez and López (2008) for Chile).
} 
rates and firms' real decisions. This strand of literature indicates that a rise in borrowing costs will have a negative impact on fixed investment, employment decisions and survival chances at the firm-level (Nickell and Nicolitsas (1999); Benito (2005); Benito and Young (2007); and Guariglia et al. (2013)). Therefore, we should expect a change in debt-servicing costs to affect export exit decisions.

To preview our findings, we find indeed that export market exit has increased during the crisis. We also find that the role of firms' financial status in export failure is significantly more important in the crisis compared to the pre-crisis period. Financial health measured in terms of liquidity and leverage significantly affects exporters' probability of exiting the export market, especially so during the crisis. As for the borrowing ratio, export exit appears to be more sensitive to changes in financial indicators during the crisis for exporters charged a higher firm-specific interest rate.

The paper is structured as follows. The next section discusses in more detail the link between finance and exit from the export market. Section 3 presents the firm level data, Section 4 outlines the methodology and Section 5 discusses our econometric results. We summarise our findings and provide some conclusions in Section 6.

\section{Finance and export market exit}

In the UK, business lending, which has been falling steadily for the last four years, plunged below 400 billion pounds by the beginning of May 2013. That is $20 \%$ below its level four

years ago. Participants in the Funding for Lending Scheme group, which includes all of the big high-street banks except HSBC, cut credit by 300m in the first quarter of 2013 (The Economist (2013)). A recent US study has shown that banks with less deposit financing and more credit lines outstanding reduced the number of loans and cut their lending during the crisis (Ivashina and Scharfstein (2010)). Further evidence is provided by Santos (2011), who finds that loan spreads increased during the crisis whereas the size of loans decreased. 
In addition, banks with larger losses during the crisis increased the spreads on their loans to bank-dependent borrowers only. Bell and Young (2010) find evidence of a substantial tightening in credit supply from mid-2007. They argue that loan spreads on SMEs rose during the crisis period, with syndicated loans presenting a sharp increase from mid-2008. Even more recently, access to finance remains a major barrier to growth for more than 1 in 5 UK small firms with $41 \%$ of loan applications refused in the 1st quarter of 2012 (Federation of Small Businesses). It is evident that the collapse of the supply of loans to non-financial firms has negatively affected firms' activities (employment, investment, survival prospects) which in turn led to a sharp drop in economic activity. Chodorow-Reich (2012) finds that the withdrawal of credit explains between $1 / 3$ to $1 / 2$ of the employment decline of small and medium firms in the US in the year following the collapse of Lehman. By contrast, the availability of credit supply had no effect on the employment level of large firms.

According to the financial accelerator theory, deteriorations in economic conditions increase the cost of finance, which in turn weakens firms' balance sheet positions, thus influencing their activities (Bernanke et al. (1996)). Given that debt-servicing costs increased during the recent crisis, as it is evident by our data statistics, we evaluate the effects of different levels of the borrowing ratio on firm export exit, and assess whether these effects were magnified during the financial crisis. We should expect the increase in borrowing ratio associated with the cost of servicing debt to have a significant impact on firms' survival in the export market. Firms dependent on bank finance are more likely to face an increase in their debt servicing cost. Given the high degree of heterogeneity across firms in our dataset and the fact that the vast majority are unquoted, mainly dependent on bank finance, we expect to identify a differential impact of the firm-specific interest rate on export exit. ${ }^{5}$ Thus, firms paying a higher borrowing ratio might face an increased probability to exit the export market during the crisis compared to those firms which pay a lower rate. The increase in loan spreads together with the deterioration of the financial position of exporting firms might

\footnotetext{
${ }^{5}$ As we discuss in the data section, the majority of companies in our sample are SMEs.
} 
have been detrimental for their survival in the export market.

\section{$3 \quad$ Data and summary statistics}

To assess the link between firms' financial conditions and their probability to exit the export markets, we construct our data set from the profit and loss and balance sheet data gathered by Bureau Van Dijk Electronic Publishing in the FAME database. ${ }^{6}$

In addition to financial information, FAME also assigns companies a four-digit UK SIC code which we use to classify firms and construct industry dummy variables. Our sample is limited to firms that operate in the manufacturing industry. ${ }^{7}$

The percentage of exporting firms in our dataset is $52 \%$ which is similar to Greenaway et al. (2007) who also use FAME data and find that $62 \%$ of the UK firms export their products.

Our database includes a majority of firms (99.9\%) which are not traded on the stock market or which are quoted on alternative exchanges such as the Alternative Investment Market (AIM) and the Off-Exchange (OFEX) market. This feature of the data allows for a wide degree of variation across observations in our sample. A distinctive characteristic is that not only small and medium sized firms are included in our sample but also some large firms that are more likely to export. Having such detailed financial data is of particular importance for the evaluation of firms' probability to exit the export market given the high degree of heterogeneity across firms. Private companies in our data are generally the smallest, youngest, and most-bank dependent firms. They are therefore more likely than public companies to face financial constraints and difficulties in accessing bank finance. This enables us to examine the effect of firm-specific interest rate on export market exit.

Looking at the quartile distribution of various size measures in Table A1 in the Appendix,

\footnotetext{
${ }^{6} \mathrm{~A}$ maximum of 10 years of complete data history can be downloaded at once. Our data were downloaded in October 2010: the coverage period is therefore 2000-2009.

${ }^{7}$ Firms are allocated to one of the following nine industrial groups: food, drink and tobacco; textiles, clothing, leather and footwear; chemicals and man made fibres; other minerals and mineral products; metal and metal goods; electrical and instrument engineering; motor vehicles and parts, other transport equipment; mechanical engineering; and others.
} 
we observe the variation over firms in terms of turnover, total assets and number of employees. The median UK firm in our sample has an average of 85 employees, 4.7 mill. assets and 9.5 mill. turnover which falls in the small and medium-sized enterprise category. ${ }^{8}$

In order to model the hazard of export market exit we define Export Exiters as those firms that exported in $t-1$ and $t-2$ but not in $t$.

Further, we follow the literature on export participation (Greenaway et al. (2007), Bellone et al. (2010) and Bricongne et al. (2012)) and employ two financial variables to control for changes in the financial status of the firms. The first one is liquidity (LIQUIDITY), which is defined as the firm's current assets less current liabilities over total assets and it is an indicator of the liquid assets of the firm. The higher the liquidity ratio the better the financial position of the firm. We expect to find a negative effect of liquidity on the hazard of export exit. The second financial characteristic is leverage ( $L E V E R A G E)$, which is measured as the firm's short-term debt to assets ratio. A high leverage ratio is associated with a worse balance sheet situation. This may increase moral hazard and adverse selection problems, and lead to the inability of firms to obtain external finance at a reasonable cost. We should expect a positive relationship between leverage and the exit hazard in the export market. Both measures proxy for the general financial health of the firms.

To assess the role of the firm-specific interest rate in the hazard of export exit, we employ the borrowing ratio. This is motivated by Nickell and Nicolitsas (1999), Benito (2005), Benito and Young (2007) and Guariglia et al. (2013), who show that higher levels of interest payments negatively affect fixed investment, employment decisions and survival chances at the firm-level. We measure the borrowing ratio using the ratio of interest payments to cash flow. Increases in firm-specific interest rates should lead to an increase in the risk of export failure. Although this indicator is not controlled exogenously by the Bank of England (it is

\footnotetext{
${ }^{8}$ In the UK, sections 382 and 465 of the Companies Act 2006 define a SME for the purpose of accounting requirements. According to this a small company is one that has a turnover of not more than 6.5 million, a balance sheet total of not more than 3.26 million and not more than 50 employees. A medium-sized company has a turnover of not more than 25.9 million, a balance sheet total of not more than 12.9 million and not more than 250 employees.
} 
endogenous in the sense that it reflects the financial conditions of firms as well as the interest rate), it does provide evidence about the extent of the asymmetric information problem in the financial transactions given firm heterogeneity (Bougheas et al. (2006)). Thus, we expect to find a significant role for borrowing costs in shaping export survival.

In addition to financial indicators, we also control for other firm-specific characteristics and macroeconomic factors. As suggested by e.g., Greenaway et al. (2007), Bellone et al. (2010) and Bricongne et al. (2012), we also control in the empirical model for firm size and age. $S I Z E$ is defined as the firm's real total assets whereas, $A G E$ is defined as the difference between the current year and the date of incorporation.

Girma et al. (2003), Ilmakunnas and Nurmi (2010) and Askenazy et al. (2011) have recognized that productivity is one of the most important determinants of export market survival. We construct labour productivity as sales per employee. We anticipate more productive firms to be less likely to exit the export market. Further, Ilmakunnas and Nurmi (2010) and Alvarez and López (2008) control for macroeconomic influences and they find that changes in real exchange rate and real GDP can affect firms' export exit. We also control for macroeconomic conditions by including the real effective exchange rate. ${ }^{9}$ Appreciation of the trading currency has an adverse effect on both the intensive and extensive margins (Bernard and Jensen (2004)). We expect the exchange rate (EXCHANGE) to increase the likelihood to exit the export market.

In order to clean our data we apply selection criteria that are common in the literature, and exclude firm-years with negative sales. To control for the potential influence of outliers, we excluded observations in the 0.5 percent from the upper and the lower tails of the distribution of the regression variables. These cut-offs are aimed at eliminating extraordinary firm shocks, or coding errors. Next, we delete from our sample firms that report only consolidated accounts, to avoid double-counting firms and subsidiaries or operations abroad. Our final panel has an unbalanced structure with a total of 142,774 annual observations (firm-years)

\footnotetext{
${ }^{9}$ Following the Bank for International Settlements' methodology, we calculate the effective exchange rate as geometric weighted averages of bilateral exchange rates adjusted by relative consumer prices.
} 
on 14,533 UK firms.

Table 1 presents descriptive statistics of all variables used in our empirical models for the entire sample. Means and standard deviations of the main variables of interest are reported for the entire sample (column 1), for exiters and non-exiters (columns 2 and 3); and crisis and tranquil periods (columns 5 and 6). We define the crisis as 2007 - 2009, as in Alfaro and Chen (2012).

In columns 4 and 7 we report p-values of a test for the equality of means. Starting with the financial variables, we observe that export exiters are more indebted (leverage), less liquid and they face a higher borrowing ratio compared to non-exiters. Exiters are also less productive, older and smaller firms. There appear to be statistically significant differences between exiters and non-exiters in all cases. This preliminary evidence points to the fact that export market exit and a deterioration in a firms' financial position are correlated. ${ }^{10}$

When comparing the 2007-09 financial crisis period with the earlier years of our sample (columns 5 and 6), we observe that the borrowing ratio is higher during the crisis. This difference is statistically significant at the $1 \%$ level (column 7 ). Note that this variable takes the value of $37.6 \%$ during the crisis, while it equals $30.8 \%$ during tranquil periods. ${ }^{11}$ This suggests that during the financial crisis firms faced an increase in their debt-servicing costs.

Focusing on the remaining financial variables, we note that the leverage ratio displays lower values during the crisis period. This is consistent with the notion that firms took a substantial amount of short-term debt in the pre-crisis period and perhaps were unable to extend it further in the later years of our sample. In addition, we find that liquidity is higher during the crisis than in other times. It is likely that firms boosted their holdings of cash and other liquid assets as a buffer due to the uncertainty in credit markets. ${ }^{12}$ Mean differences

\footnotetext{
${ }^{10}$ Girma et al. (2003) and Ilmakunnas and Nurmi (2010) show that firms that exit from export markets are smaller in terms of employment and output, and less productive which is in line with this conjecture.

${ }^{11}$ The average borrowing ratio in our sample is comparable with Guariglia et al. (2013) and Benito and Young (2007), although the latter study focuses on UK listed companies and hence it reports a somewhat smaller figure.

${ }^{12}$ According to SEC Filings (Securities and Exchange Commission), the main reason that firms drew down on the credit line was to enhance their liquidity and financial flexibility during the credit crisis (Ivashina and Scharfstein (2010))
} 
are statistically significant in all cases.

To summarise, two points can be highlighted from these preliminary statistics. First, a firm's financial health appears to be correlated with export market exit. Second, high borrowing costs relative to cash flow, are related to the probability that a company will exit the export market. In the following sections we provide formal econometric evidence to account for the confounding effects of financial and other factors that may influence the incidence of export exit.

\section{Econometric methodology}

To evaluate the differential effects of financial status and firm-specific interest rate on the likelihood of exiting the export market, we use a complementary log-log model (cloglog), a discrete time version of the Cox proportional hazard model. ${ }^{13}$

The assumption of the proportional hazard model is that the hazard ratio depends only on time at risk, $\theta_{0}(t)$ (the so-called baseline hazard) and on explanatory variables affecting the hazard independently of time, $\exp \left(\beta^{\prime} K\right)$. The hazard ratio is then given by:

$$
\theta(t, K)=\theta_{0}(t) \exp \left(\beta^{\prime} K\right)
$$

The discrete-time hazard function, $h(j, K)$, shows the interval hazard for the period between the beginning and the end of the $j^{\text {th }}$ year after the first appearance of the firm. This hazard rate, which is the rate at which firms fail at time $t$ given that they have survived in $t-1$, takes the following form:

$$
h(j, K)=1-\exp \left[-\exp \left(\beta^{\prime} K+\gamma_{j}\right)\right]
$$

where we are particularly interested in identifying the $\beta$ parameters, which show the

\footnotetext{
${ }^{13}$ To capture the particular nature of the dataset, given that it is collected on a yearly basis, the cloglog model is more appropriate than the standard Cox model. See Jenkins (2005) for an excellent overview of complementary log-log and proportional hazard models.
} 
effect of the explanatory variables incorporated in vector $K$ on the hazard rate. ${ }^{14}$

We set out a benchmark model to estimate how firms' probability to exit the export market is affected by their financial conditions:

$$
h(j, X)=1-\exp \left[-\exp \left(\beta_{0}+\beta_{1} X+\beta_{2} Y+\gamma_{j}\right)\right]
$$

where $X$ is a vector of financial variables Liquidity and Leverage. Both variables capture different aspects of the financial health of a firm. The sign and significance of $\beta_{1}$ shows the importance of financial health on the probability of firms to exit the export market. $Y$ denotes the vector of control variables size, age, labour productivity and exchange rate. In addition, our model includes a full set of time, industry and regional dummies. To obtain efficient estimators and unbiased standard errors we apply the Huber-White sandwich or robust estimator.

In order to examine whether the hazard of export market exit differs in crisis years compared to tranquil periods, we augment Equation 4.3 with a financial crisis dummy $(C R I S I S)$, which takes value one over the period 2007-09, and zero otherwise. The financial crisis might have an indirect impact on exit by magnifying the effect of financial variables on firms' likelihood to exit the export market.

$$
h(j, X)=1-\exp \left[-\exp \left(\beta_{0}+\beta_{1} X * \text { Crisis }+\beta_{2} X *(1-\text { Crisis })+\beta_{3} Y+\gamma_{j}\right)\right]
$$

Deteriorations in economic conditions increase the cost of finance, which in turn weakens firms' balance sheet positions, thus influencing their activities. In these circumstances, worsening of our financial indicators might increase the risk of export failure during the crisis. The sign and significance of the interacted terms will reveal the extent to which the impact

\footnotetext{
${ }^{14}$ gamma $_{j}$ is the $\log$ of the difference between the integrated baseline hazard evaluated at the end and the beginning of the interval. It, thus, captures duration dependence. We do not impose any restrictions on these parameters, rather we estimate a full set of gamma $_{j}$ time dummies.
} 
of financial variables on export market exit differs during tranquil and turbulent periods. We expect the effects of changes in the level of financial characteristics on firms' export market exit to be stronger during the crisis (i.e. we expect to observe that $\beta_{1}>\beta_{2}$ ).

The main aim of the paper is to assess whether changes in the financial condition of firms in and out-of-the crisis will have a differential impact on their probability to exit the export markets, taking into account heterogeneity in interest payment obligations. To test this hypothesis we employ the borrowing ratio to capture the effects of a change in debtservicing costs on the export exit. We split our sample into high and low borrowing ratio firms to capture the differences in debt servicing costs considering the impact of the crisis on the hazard of export exit. We define a firm as high borrowing ratio $(H B R)$ in a given year if its borrowing ratio falls in the top $50 \%$ of the BR distribution of all firms operating in the same industry as this firm in that year, and 0 otherwise. Based on recent evidence (Santos (2011) and Bell and Young (2010)), which indicate an increase in loan spread during the crisis and document that UK banks interrupted lines of credit due to liquidity problems, we should expect firms with high interest payment obligations to have suffered more during 2007-09 than firms with low interest payment obligations.

We modify equation 4.4 to contain interaction terms between the $H B R$ dummy, the crisis dummy and financial indicators. This yields the following empirical model:

$$
\begin{aligned}
& h(j, X)=1-\exp \left[-\exp \left(\beta_{0}+\beta_{1} X * \text { Crisis } * H B R+\beta_{2} X *(1-\text { Crisis }) * H B R\right.\right. \\
& \left.\left.+\beta_{3} X * C r i s i s *(1-H B R)+\beta_{4} X *(1-\text { Crisis }) *(1-H B R)+\beta_{5} Y+\gamma_{j}\right)\right]
\end{aligned}
$$

The sign and significance of the interacted terms reveal whether firms facing a higher (lower) firm-specific interest rate are less (more) likely to survive in the export market during the crisis compared to the tranquil periods. 


\section{$5 \quad$ Econometric results}

\subsection{Survival in the export market during the recent crisis}

In order to provide a benchmark we begin the econometric analysis by estimating equations (4.3 and 4.4). The results are presented in Table 2. The predicted probability of exiting the export market evaluated at the mean of the independent variables, is $38 \%$. The first column of the Table presents the direct effect of the financial variables without considering the crisis dummy, column 2 includes the crisis dummy along with the financial indicators, and column 3 reports the indirect effect of the financial crisis on the hazard of export market exit.

To start with column 1, liquidity negatively affects the likelihood of firms exiting the export market. More liquid firms are more likely to continue financing their operations in the international market. Our debt measure, leverage is found to exert a positive effect on the hazard of export market exit. High levels of debt would increase moral hazard and asymmetric information problems, and would lead to a higher probability of export failure. This is in line with expectations since evidence presented by other studies ( Greenaway et al. (2007), Bellone et al. (2010) and Bricongne et al. (2012)) reveal a positive impact of liquidity and a negative impact of debt on export entry and export performance.

Column 2 includes the crisis dummy and is aimed at evaluating the marginal effect of the crisis on export exit, holding everything else equal. The crisis dummy attracts a positive coefficient with a sizeable effect on failure. During downturns, economic activity faces a general slowdown which is likely to affect the survival in the export market.

In column 3 we include the interactions between the financial indicators and the crisis terms in order to assess the differential impact of the 2007-09 crisis on the hazard of export exit. Comparing the role of liquidity during and outside crisis, we observe that the hazard of export market exit is more sensitive to changes in the level of liquidity in the crisis. This is equivalent to a reduction in the predicted exit probability by around 18 percentage points. ${ }^{15}$

\footnotetext{
${ }^{15}$ This is calculated at the mean exit probability of $38 \%$, using the exponentiated coefficient: 1 -exp(-0.690)
} 
During economic downturns the external finance premium increases for some firms and access to external funding might become prohibitively expensive. Therefore, liquid firms are more likely to overcome financial problems and continue operating in international markets. The impact of liquidity during tranquil periods appears to be less significant. A $1 \%$ increase translates into a decrease in the predicted export exit probability by around 8.9 percentage points.

In terms of leverage, we find again a stronger effect during the crisis. Higher levels of debt are often associated with an unhealthy balance sheet indicating that highly leveraged firms face greater difficulties obtaining funds on the markets, especially during extreme economic conditions. Our findings are not only statistically but also economically important since a $1 \%$ increase in leverage translates into an increase in the predicted export exit probability during the crisis by around $11 \%$ compared to a $3 \%$ increase during tranquil periods.

Finally, in terms of the control variables, we find the expected relationships for productivity and exchange rate, while the effect of size and age is of less importance for the export exit.

\subsection{The role of the borrowing ratio for export market exit}

In this section we set out to investigate the main concern of this paper, namely, whether firms with different levels of debt servicing costs exhibit different effects of financial variables on their survival in the export market in and out of the crisis. A priori, we would expect changes in firms' financial conditions to make firms with a high level of borrowing ratio (HBR) more vulnerable during the crisis, as they face an increase in their interest payment obligations.

In order to look at these issues we estimate equation (4.5) where we interact our financial variables with the crisis/(1-crisis) dummies and the HBR/(1-HBR) dummies to gauge the $=0.49,(0.49 * 0.38)=18 \%$ 
extent to which the effects of firms' financial condition on the likelihood of export exit differ for HBR and (1-HBR) firms throughout the business cycle.

The empirical results are reported in Table 3 for two measures of the borrowing ratio and a test for equality of coefficients is shown at the foot of the table. To ensure that our results are robust, we carry out our estimations using an alternative measure of borrowing ratio which takes into account the interest payments as a fraction of total debt (BR2). We follow Benito and Whitley (2003) and construct the implicit interest rate, which is defined as the ratio of interest payments to a moving average of three year of data on the debt variable centred on the current year. ${ }^{16}$

Focusing on rows 1 and 2 of Table 3, we observe that for HBR firms, liquidity exhibits a larger coefficient during the crisis than outside. The test for the equality of the coefficients shows that the differences in the coefficients on liquidity for HBR firms during and before the crisis are statistically significant. We next compare rows 3 and 4 and observe that the estimated coefficients on liquidity are negative and significant for (1-HBR) firms both in and out of the crisis, and generally higher in the crisis. The p-values for the test of the differences in these coefficients show that they are statistically significant. We repeat the same exercise for leverage. In particular, the coefficients on leverage carry the expected positive sign and exert a significant impact on export exit. Yet, the tests of equality indicate that the impact of leverage on export exit is significantly higher during the crisis than out-of-the crisis only for HBR firms. Overall, results indicate that the survival of firms in the export market is more sensitive to changes in the level of financial indicators during the crisis for firms with high firm-specific interest rate (HBR).

Next, we compare the coefficients on liquidity at HBR and (1-HBR) firms during the

\footnotetext{
${ }^{16}$ The mean value of interest payments is in fact 495,097 during the crisis period, and 430,504 during the tranquil period. The difference between these two mean values is statistically significant at the $1 \%$ significance level $(\mathrm{p}$-value $=0.000)$. However, we observe a drop in total debt during the 2007-09 crisis compared to the previous periods $(9,893,000$ and $11,855,000$ respectively). Their difference is statistically significant $(p$-value $=0.000)$. This suggests that some of the deleveraging by bank-reliant companies was driven by the contraction in bank lending. Statistics confirms that during the financial crisis firms faced an increase in their debt-servicing cost.
} 
crisis (rows 1 and 3). We observe that the sensitivity of export market exit to changes in liquidity is much higher for the former group of firms. The p-values reported at the foot of the Table reveal that during the crisis the coefficients on liquidity for HBR firms are significantly different from those of (1-HBR) firms. The same pattern is evident for leverage. During the 2007-09 financial crisis firms with high interest payment obligations were more likely to exit the export market compared to firms with lower interest payment costs. A higher borrowing ratio has a significant positive effect on the hazard of export exit. This suggest that companies respond, at least in part, to increases in borrowing ratio by exiting the export market.

Access to capital markets is likely to be prohibitively expensive for firms that are likely to face credit constraints and which are more likely to depend on banks for external finance. It is in fact documented that during the crisis, loan spreads increased (Santos (2011) and Bell and Young (2010)) leading to a drop in the demand of loans and a shift to alternative sources of finance. It is also noteworthy that banks tightened lending standards. As a consequence of this, those bank-dependent firms had to scale back their investment projects and restrain their activities. According to Aghion et al. (2012), the failure of a firm to pay its creditors during the previous year (payment incident) will have a negative and significant impact on the amount of any new bank loan. It will adversely affect the probability of contracting a new loan and the size of a new loan. Bricongne et al. (2012) show that small exporters display the highest number of a payment incident and further, they have been forced to stop exporting during the crisis. Therefore, it is not surprising that following a rise in their debt obligations, HBR firms faced an increase in the risk to exit the export market during the crisis.

The last pair of interactions to be compared are those in rows 2 and 4 . Results for both HBR and (1-HBR) firms during tranquil periods are mixed. When we employ the first measure of the borrowing ratio (column 1), the impact of liquidity and leverage on export exit for both HBR and (1-HBR) firms is significant. Yet, we find that the differences 
in the relevant coefficients are not statistically significant. When the focus is the second measure of the borrowing ratio (column 2), we show that the differences in the coefficients are statistically significant.

In sum, the greater sensitivities of export exit to changes in financial variables documented for HBR firms during the crisis suggest that rising interest payments may have been one of the driving factors explaining the exit of exporting firms during the crisis.

\section{Robustness Checks}

In this section we provide a series of robustness checks of our results. Firstly, we limit our sample to firms that start to export over the period we analyze. Secondly, we estimate our models by re-defining the export exiters dummy variable. Thirdly, we examine whether our findings remain persistent when we control for possible endogeneity and heterogeneity

problems. Finally, we set an alternative crisis dummy for the period 2008-09 and we also test its full effect on export exit.

\section{Using only firms that start to export over the period we analyze}

To start with, we follow Ilmakunnas and Nurmi (2010) and estimate an alternative model where we focus on new exporters. This allows us to avoid one possible aspect of firm heterogeneity, namely, differences between new and continuous exporters, which may otherwise bias our results (Görg and Spaliara (2013)). Hence, we evaluate the role of financial status and financial pressure in export exit probability of firms that started exporting for the first time after 2000. The results are reported in Tables 4 and 5 (column 1). We can see that overall our findings do not change significantly compared to Tables 2 and 3. 


\section{Alternative definition of export exiters}

We perform a further robustness check involving a change in the definition of exiters. The export exit dummy is re-defined in order to correctly identify firms which definitely exit the foreign market and do not start exporting again during our sample period. Therefore, export switchers do not count as exiters. Results remain robust to this change. Table 4 (column 2) shows that during the crisis indebted exporters are more likely to exit the export market whereas liquid exporters are more likely to continue their exporting activities. Further, results in Table 5 reveal that the sensitivity of export exit to financial indicators is higher during the crisis mainly for the group of firms charged a higher firm-specific interest rate.

\section{Control for heterogeneity}

The simple complementary log-log model used thus far does not allow for unobserved firm heterogeneity. To do so we use the random-effects version of the cloglog model as a robustness check. In Tables 4 and 5 we report the estimations of Equations (4.4 and 4.5) using this alternative estimator. Results are largely comparable with the simple cloglog model presented in Tables 2 and 3. Thus, we can conclude that our main findings are unlikely to be biased due to unobserved firm heterogeneity.

\section{Instrumental variables}

The next robustness check deals with the potential endogeneity of the borrowing ratio and financial indicators in our model. We use instrumental variables techniques, assuming that the financial variables are potentially endogenous. We use lagged values of liquidity, leverage and size as instruments. We also instrument the borrowing ratio using as exogenous instruments the base interest rate and the ten year government bond yield. ${ }^{17}$ The results are robust to this modification.

\footnotetext{
${ }^{17}$ The data were taken from the Bank of England website.
} 
In order to test the validity and the relevance of our instruments we estimate a linear instrumental variables model using the same set of instruments as in the IV probit model. The Hansen J test statistic of the overidentifying restrictions suggests that our instruments are valid and further, the Kleibergen-Paap test statistic rejects the null and suggests that the model is identified therefore the instruments are correlated with the endogenous variables. Hence, our main results in Tables 4 and 5 (column 4) are not biased due to endogeneity of regressors.

\section{Alternative definition of the crisis}

So far we have used years 2007-09 to define the crisis period, following Alfaro and Chen (2012). As a robustness check, we define the crisis dummy to take value one over the period 2008-09, and zero otherwise. Results in Tables 4 and 5 (column 5) confirm the findings

discussed in section 5. The sensitivity of the hazard of export exit to liquidity and leverage is greater during the crisis. Once again the sensitivity appears to be more significant during the crisis for firms which face a rise in borrowing costs (HBR). Therefore, our results do not appear to be driven by the definition of the crisis dummy.

\section{Full effect of the crisis}

The final test is to investigate the full effect of the crisis on export exit. To examine whether the crisis dummy exerts a significant direct effect on export exit after controlling for its indirect impact, we incorporate the crisis dummy on its own along with the interacted terms in Equations 4.4 and 4.5. Results are presented in Tables 4 and 5 (column 6). They show that the crisis has a positive and statistically significant effect on export market exit. More importantly, the inclusion of the dummy does not change the results on the interaction terms. 


\section{Conclusion}

We use firm level data for the UK to investigate the link between firms' financial health, the borrowing ratio and export exit. In particular, we look at whether firms which face different levels of borrowing ratios react differently to changes in financial variables during crisis and tranquil periods. This may be expected as firms' real activities are adversely affected by a rise in borrowing costs which provides strong evidence in favour of a monetary policy effect through the changes in the costs of debt servicing.

Our empirical results show that the impact of access to finance on the hazard of export market exit differs is exacerbated during the crisis. In general, changes in the financial status of the firm have a much stronger impact on the risk of export failure during the recent financial crisis than the outside period. Most importantly, we find that increases in debt servicing costs positively affect the likelihood of export exit during the crisis. Firms facing high interest payment obligations are more likely to exit the export market during 2007-09 compared to firms with lower interest payments.

An increase in the number of firms dropping out of export markets during the crisis should be of concern to policy makers. These firms are unlikely to simply re-enter export markets after the crisis, since sunk costs are important for export decisions. Instead, they may behave just like first time exporters, relying on the same export promotion policies as firms that have never exported before.

\section{Appendix}

\section{Definitions of the variables}

Export exiter: dummy variable equal to 1 if the firm exported in $t$ - 1 and $t$ - 2 but not in $t$.

$B R$ : ratio of interest payments to profit and loss after taxes plus depreciation.

BR2: ratio of interest payments to a moving average of three year of data on total debt. 
Leverage: ratio of short term debt to total assets.

Liquidity: ratio of current assets less current liabilities to total assets.

Size: logarithm of real total assets.

Age: difference between the present year and the firm's date of incorporation.

Productivity: labour productivity defined as sales per employee

Exchange Rate: effective exchange rate calculated as a geometric weighted average of bilateral exchange rates adjusted by relative consumer prices.

Deflators: all variables are deflated using the industry-specific price of output

\section{References}

Aghion, P., Askenazy, P., Berman, N., Cette, G. and Eymard, L. (2012). Credit constraints and the cyclicality of R\&D investment: Evidence from France. Journal of the European Economic Association, 10, 1001-1024.

Alfaro, L. and Chen, M. (2012). Surviving the global financial crisis: Foreign ownership and establishment performance. American Economic Journal: Economic Policy, 4, 30-55.

Alvarez, R. and López, R. (2008). Entry and exit in international markets: Evidence from Chilean data. Review of International Economics, 09, 692-708.

Amiti, M. and Weinstein, D. (2011). Exports and financial shocks. Quarterly Journal of Economics, 126, 1841-1877.

Askenazy, P., Caldera, A., Gaulier, G. and Irac, D. (2011). Financial Constraints and Foreign Market Entries or Exits: Firm Level Evidence from France. Working Paper 328, Banque de France.

Baldwin, R. (1990). Hysteresis in trade. Empirical Economics, 15, 127-142.

- and EvenetT, S. (2009). The collapse of global trade, murky protectionism, and the crisis. Recommendations for the G20. Working paper, Centre for Economic Policy Research.

Bell, V. and Young, G. (2010). Understanding the weakness of bank lending. Quarterly Bulleting Q4, Bank of England.

Bellone, F., Musso, P., Nesta, L. and Schiavo, S. (2010). Financial constraints and firm export behaviour. The World Economy, 33, 347-373.

Benito, A. (2005). Financial pressure, monetary policy effects and inventories: Firm-level evidence from a market based and bank based financial system. Economica, 72, 201-224.

- and Whitley, J. (2003). Implicit interest rates and corporate balance sheets: An analysis using aggregate and disaggregated UK data. Working Paper 193, Bank of England. 
- and Young, G. (2007). Financial pressure and balance sheet adjustment by firms. Oxford Bulletin of Economics and Statistics, 69, 581-602.

Berman, N. and Hericourt, J. (2010). Financial factors and the margins of trade: Evidence from cross-country firm-level data. Journal of Development Economics, 93, 206-217.

Bernanke, B., Gertler, M. and Gilchrist, S. (1996). The financial accelerator and the flight to quality. Review of Economics and Statistics, 78, 1-15.

Bernard, A. and Jensen, J. (2004). Entry, expansion, and intensity in the us export boom, 1987-1992. Review of International Economics, 12, 662-675.

Bougheas, S., Mizen, P. and Yalcin, C. (2006). Access to external finance: Theory and evidence on the impact of firm-specific characteristics. Journal of Banking and Finance, 30, 199-227.

Bricongne, J., Fontagn, L., Gaulier, G., Taglioni, D. and Vicard, V. (2012). Firms and the global crisis: French exports in the turmoil. Journal of International Economics, 87, 134-146.

Chodorow-Reich, G. (2012). The Employment Effects of Credit Market Disruptions: Firm-level evidence from the 2008-09 financial crisis. Mimeo, UC Bercley.

Chor, D. and Manova, K. (2012). On the cliff and back? Credit conditions and international trade during the global financial crisis. Journal of International Economics, 87, $117-133$.

Das, S., Roberts, M. and Tybout, J. (2007). Market entry costs, producer heterogeneity, and export dynamics. Econometrica, 75, 837-873.

Engel, D., Procherc, V. and Schmidt, C. (2013). Does firm heterogeneity affect foreign market entry and exit symmetrically? Empirical evidence for French firms. Journal of Economic Behavior and Organization, 18, 381397.

Forlani, E. (2010). Liquidity constraints and firm's export activity. Mimeo, CORE Louvain.

Girma, S., Greenaway, D. and Kneller, R. (2003). Export market exit and performance dynamcis: A causality analysis of matched firms. Economics Letters, 80, 181-187.

Görg, H. and Spaliara, M.-E. (2013). Financial health, exports, and firm survival: Evidence from UK and French firms. Economica.

Greenaway, D., Guariglia, A. and Kneller, R. (2007). Financial factors and exporting. Journal of International Economics, 73, 377-395.

Guariglia, A., Spaliara, M. and Tsoukas, S. (2013). To what extent does the interest burden affect firm survival? Evidence from a panel of UK firms during the recent financial crisis. Mimeo, University of Glasgow.

Harris, R. and Li, Q. (2011). The determinants of firm exit from exporting: Evidence for the UK. International Journal of the Economics of Business, 18, 381397.

Hiller, S., Schröder, S. and Sørensen, A. (2013). Export market exit and firm survival:Theory and first evidence. Working Paper 262, University of Lüneburg.

Ilmakunnas, P. and Nurmi, S. (2010). Dynamics of export market entry and exit. Scandinavian Journal of Economics, 112, 101-126. 
Impullitti, G., Irarrazabal, A. and Opromolla, L. (2013). A theory of entry into and exit from export markets. Journal of International Economics, 90, 75-90.

Ivashina, V. and Scharfstein, D. (2010). Bank lending during the financial crisis of 2008. Journal of Financial Economics, 97, 319-338.

Jenkins, S. (2005). Survival Analysis. Mimeo, University of Essex.

Minetti, R. and Zhu, S. (2011). Credit constraints and firm export: Microeconomic evidence from Italy. Journal of International Economics, 83, 109-125.

Mû́Ls, M. (2005). Exporters and credit constraints: A firm level approach. Working Paper 139, National Bank of Belgium.

Nickell, S. and Nicolitsas, D. (1999). How does financial pressure affect firms? European Economic Review, 43, 1435-1456.

Roberts, M. and Tybout, J. (1997). The decision to export in Colombia: An empirical model of entry with sunk costs. American Economic Review, 87, 545-564.

Santos, J. (2011). Bank corporate loan pricing following the subprime crisis. The Review of Financial Studies, 24, 1916-1943.

The Economist (2013). Innovative new lenders are easing the credit crunch for British firms. article 8 June.

WAGneR, J. (2012). The post-entry performance of cohorts of export starters in German manufacturing industries. International Journal of the Economics of Business, 2, 169-193.

WTO (2012). World Trade Technical Report. Tech. rep., World Trade Organization. 
Table 1: Summary Statistics

\begin{tabular}{lccccccc}
\hline & Total Sample & $\begin{array}{c}\text { Exiter=1 } \\
(1)\end{array}$ & $\begin{array}{c}\text { Exiter=0 } \\
(2)\end{array}$ & $\begin{array}{c}\text { Diff. } \\
(4)\end{array}$ & $\begin{array}{c}\text { Crisis=1 } \\
(5)\end{array}$ & $\begin{array}{c}\text { Crisis=0 } \\
(6)\end{array}$ & $\begin{array}{c}\text { Diff. } \\
(7)\end{array}$ \\
\hline Leverage & 0.374 & 0.381 & 0.367 & 0.000 & 0.321 & 0.387 & 0.000 \\
& $(0.30)$ & $(0.31)$ & $(0.30)$ & & $(0.27)$ & $(0.32)$ & \\
Liquidity & 0.143 & 0.138 & 0.151 & 0.000 & 0.198 & 0.129 & 0.000 \\
& $(0.26)$ & $(0.26)$ & $(0.29)$ & & $(0.25)$ & $(0.26)$ & \\
Borrowing Ratio & 0.363 & 0.391 & 0.339 & 0.000 & 0.376 & 0.308 & 0.000 \\
& $(0.37)$ & $(0.38)$ & $(0.36)$ & & $(0.38)$ & $(0.34)$ & \\
Size & 4.436 & 4.579 & 4.311 & 0.000 & 4.285 & 4.475 & 0.000 \\
Age & $(1.38)$ & $(1.35)$ & $(1.39)$ & & $(1.29)$ & $(1.40)$ & \\
& 26.748 & 27.069 & 26.470 & 0.031 & 28.550 & 26.278 & 0.000 \\
Productivity & $(23.71)$ & $(24.37)$ & $(23.40)$ & & $(23.44)$ & $(23.75)$ & \\
& 2.104 & 2.066 & 2.137 & 0.000 & 2.206 & 2.078 & 0.000 \\
Exchange & $(0.85)$ & $(0.82)$ & $(0.88)$ & & $(1.14)$ & $(0.75)$ & \\
& 99.099 & 100.623 & 97.770 & 0.000 & 84.218 & 102.987 & 0.000 \\
Observations & $(11.19)$ & $(10.26)$ & $(11.78)$ & & $(9.36)$ & $(7.88)$ & \\
\hline
\end{tabular}

Notes: The table presents sample means. Standard deviations are reported in parentheses. Diff. is the p-value of the test statistic for the of means. Leverage measured as the firm's short-term debt to assets ratio. Liquidity is defined as the ratio of the firm's current assets less current liabilities over total assets. Borrowing Ratio is defined as the ratio of interest payments to profit and loss after taxes plus depreciation. Size is given by the log of the firm's real assets measured in thousands of UK sterling. Age is defined as the difference between the present year and the firm's date of incorporation. Productivity denotes labour productivity defined as sales per employee. Exchange is the real effective exchange rate. Crisis takes value 1 in the years 2007-2009, and 0 otherwise. The time period is 2000-2009. 
Table 2: Baseline Model

\begin{tabular}{|c|c|c|c|}
\hline Liquidity & $\begin{array}{c}-0.326^{* * *} \\
(-8.73)\end{array}$ & $\begin{array}{c}-0.326^{* * *} \\
(-8.73)\end{array}$ & \\
\hline Liquidity ${ }^{*}$ Crisis & & & $\begin{array}{c}-0.690^{* * *} \\
(-7.11)\end{array}$ \\
\hline Liquidity $^{*}(1-$ Crisis $)$ & & & $\begin{array}{c}-0.268^{* * *} \\
(-6.71)\end{array}$ \\
\hline Leverage & $\begin{array}{c}0.097^{* * *} \\
(3.26)\end{array}$ & $\begin{array}{c}0.097^{* * *} \\
(3.26)\end{array}$ & \\
\hline Leverage ${ }^{*}$ Crisis & & & $\begin{array}{c}0.257^{* * *} \\
(2.97)\end{array}$ \\
\hline Leverage* $(1-$ Crisis $)$ & & & $\begin{array}{c}0.076^{* *} \\
(2.40)\end{array}$ \\
\hline Crisis & & $\begin{array}{c}1.534^{* * *} \\
(5.95)\end{array}$ & \\
\hline Size & $\begin{array}{c}0.090^{* * *} \\
(13.57)\end{array}$ & $\begin{array}{c}0.090^{* * *} \\
(13.57)\end{array}$ & $\begin{array}{c}0.090^{* * *} \\
(13.53)\end{array}$ \\
\hline Age & $\begin{array}{l}-0.000 \\
(-0.98)\end{array}$ & $\begin{array}{l}-0.000 \\
(-0.98)\end{array}$ & $\begin{array}{l}-0.000 \\
(-0.97)\end{array}$ \\
\hline Productivity & $\begin{array}{c}-0.025^{*} \\
(-1.92)\end{array}$ & $\begin{array}{l}-0.025^{*} \\
(-1.92)\end{array}$ & $\begin{array}{c}-0.024^{*} \\
(-1.88)\end{array}$ \\
\hline Exchange & $\begin{array}{c}0.021^{* * *} \\
(18.72)\end{array}$ & $\begin{array}{c}0.055^{* * *} \\
(8.54)\end{array}$ & $\begin{array}{c}0.024^{* * *} \\
(15.95)\end{array}$ \\
\hline Constant & $\begin{array}{c}-3.024^{* * *} \\
(-22.49)\end{array}$ & $\begin{array}{c}-7.120^{* * *} \\
(-9.25)\end{array}$ & $\begin{array}{c}-3.423^{* * *} \\
(-19.17)\end{array}$ \\
\hline Observations & 29,420 & 29,420 & 29,420 \\
\hline Log-likelihood & -19428 & -19428 & -19419 \\
\hline Test of equality & & & \\
\hline $\begin{array}{l}\text { Liquidity } \\
\text { Leverage }\end{array}$ & & & $\begin{array}{l}0.000 \\
0.045\end{array}$ \\
\hline
\end{tabular}

Notes: The dependent variable is a dummy equal to one if a firm exits the export market in year $t$, and zero otherwise. Robust z-statistics are presented in the parentheses. ${ }^{*}$ significant at $10 \%$; $* *$ significant at $5 \%$; *** significant at $1 \%$. Time dummies, industry dummies and regional dummies were included in the model. Table presents the p-values of a test for the equality of the coefficients on liquidity and leverage. Also see notes to Table 1. 
Table 3: Borrowing Ratio

\begin{tabular}{|c|c|c|}
\hline & $\begin{array}{l}\mathrm{BR} \\
(1)\end{array}$ & $\begin{array}{c}\text { BR2 } \\
(2)\end{array}$ \\
\hline Liquidity ${ }^{*}$ Crisis ${ }^{*} H B R$ & $\begin{array}{c}-0.707^{* * *} \\
(-5.41)\end{array}$ & $\begin{array}{c}-0.848^{* * *} \\
(-6.77)\end{array}$ \\
\hline Liquidity ${ }^{*}(1-C r i s i s){ }^{*} H B R$ & $\begin{array}{c}-0.306^{* * *} \\
(-6.04)\end{array}$ & $\begin{array}{c}-0.399 * * * \\
(-6.66)\end{array}$ \\
\hline Liquidity ${ }^{*}$ Crisis $*(1-H B R)$ & $\begin{array}{c}-0.455^{* * *} \\
(-5.5)\end{array}$ & $\begin{array}{c}-0.552^{* * *} \\
(-4.19)\end{array}$ \\
\hline Liquidity $^{*}(1-$ Crisis $) *(1-H B R)$ & $\begin{array}{c}-0.244^{* * *} \\
(-3.98)\end{array}$ & $\begin{array}{c}-0.230^{* * *} \\
(-4.57)\end{array}$ \\
\hline Leverage ${ }^{*}$ Crisis ${ }^{*} H B R$ & $\begin{array}{c}0.235^{* *} \\
(3.38)\end{array}$ & $\begin{array}{c}0.465^{* * *} \\
(4.38)\end{array}$ \\
\hline Leverage $*(1-$ Crisis $){ }^{*} H B R$ & $\begin{array}{c}0.089^{* * *} \\
(2.67)\end{array}$ & $\begin{array}{c}0.167^{* * *} \\
(3.68)\end{array}$ \\
\hline Leverage ${ }^{*}$ Crisis ${ }^{*}(1-H B R)$ & $\begin{array}{l}0.021 \\
(0.14)\end{array}$ & $\begin{array}{c}0.203^{* *} \\
(2.07)\end{array}$ \\
\hline Leverage $*(1-$ Crisis $) *(1-H B R)$ & $\begin{array}{c}0.161^{* * *} \\
(2.76)\end{array}$ & $\begin{array}{c}0.077^{* *} \\
(2.19)\end{array}$ \\
\hline Size & $\begin{array}{c}0.081^{* * * *} \\
(11.59)\end{array}$ & $\begin{array}{c}0.088^{* * *} \\
(12.91)\end{array}$ \\
\hline Age & $\begin{array}{l}-0.001 \\
(-1.64)\end{array}$ & $\begin{array}{l}-0.000 \\
(-1.13)\end{array}$ \\
\hline Productivity & $\begin{array}{l}-0.018 \\
(-1.34)\end{array}$ & $\begin{array}{c}-0.027^{* *} \\
(-2.07)\end{array}$ \\
\hline Exchange & $\begin{array}{c}0.024^{* * *} \\
(15.00)\end{array}$ & $\begin{array}{c}0.024^{* * *} \\
(15.18)\end{array}$ \\
\hline Constant & $\begin{array}{c}-3.327^{* * *} \\
(-17.81)\end{array}$ & $\begin{array}{c}-3.381^{* * *} \\
(-18.35)\end{array}$ \\
\hline Observations & 27,254 & 28,013 \\
\hline Log-likelihood & -18022 & -18462 \\
\hline \multicolumn{3}{|l|}{ Test of equality } \\
\hline Liquidity $* H B R$ & 0.004 & 0.000 \\
\hline Liquidity $*(1-H B R)$ & 0.039 & 0.019 \\
\hline Leverage $* H B R$ & 0.054 & 0.009 \\
\hline Leverage $*(1-H B R)$ & 0.261 & 0.225 \\
\hline Liquidity $*$ Crisis & 0.060 & 0.053 \\
\hline Liquidity $*(1-$ Crisis $)$ & 0.394 & 0.016 \\
\hline Leverage $*$ Crisis & 0.074 & 0.055 \\
\hline Leverage $*(1-$ Crisis $)$ & 0.271 & 0.031 \\
\hline
\end{tabular}

Notes: The dependent variable is a dummy equal to one if a firm exits the export market in year $t$, and zero otherwise. Robust z-statistics are presented in the parentheses. ${ }^{*}$ significant at $10 \% ;{ }^{* *}$ significant at $5 \%$; ${ }^{* *}$ significant at $1 \%$. Time dummies, industry dummies and regional dummies were included in the model. $H B R$ is a dummy equal to one if the borrowing ratio falls in the top $50 \%$ of the borrowing ratio distribution. Table presents the p-values of a test for the equality of the coefficients on the interacted terms. Also see notes to Table 1. 
Table 4: Robustness: Baseline Model

\begin{tabular}{lcccccc}
\hline & $\begin{array}{c}\text { Re-define } \\
\text { sample } \\
(1)\end{array}$ & $\begin{array}{c}\text { Re-define } \\
\text { exiter } \\
(2)\end{array}$ & $\begin{array}{c}\text { xtcloglog } \\
\text { IV }\end{array}$ & $\begin{array}{c}\text { Alternative } \\
\text { crisis } \\
(5)\end{array}$ & $\begin{array}{c}\text { Full effect } \\
\text { of crisis } \\
(6)\end{array}$ \\
\hline Liquidity $^{*}$ Crisis & $-0.321^{* * *}$ & $-1.200^{* * *}$ & $-2.024^{* * *}$ & $-0.580^{* * *}$ & $-0.633^{* * *}$ & $-0.690^{* * *}$ \\
& $(-3.11)$ & $(-6.24)$ & $(-4.11)$ & $(-4.16)$ & $(-5.20)$ & $(-7.11)$ \\
Liquidity $^{*}(1-$ Crisis $)$ & $-0.140^{* * *}$ & $-0.335^{* * *}$ & $-0.632^{* * *}$ & $-0.318^{* * *}$ & $-0.297^{* * *}$ & $-0.268^{* * *}$ \\
& $(-2.86)$ & $(-5.47)$ & $(-2.60)$ & $(-5.97)$ & $(-7.63)$ & $(-6.71)$ \\
Leverage ${ }^{*}$ Crisis & 0.075 & $0.503^{* * *}$ & $0.905^{* * *}$ & $0.387^{* * *}$ & $0.288^{* * *}$ & $0.257^{* * *}$ \\
& $(0.82)$ & $(3.10)$ & $(3.10)$ & $(2.58)$ & $(2.80)$ & $(2.97)$ \\
Leverage* $(1-$ Crisis $)$ & -0.018 & 0.021 & 0.283 & 0.042 & $0.082^{* * *}$ & $0.076^{* *}$ \\
& $(-0.46)$ & $(0.41)$ & $(1.53)$ & $(1.02)$ & $(2.63)$ & $(2.40)$ \\
Crisis & & & & & & $1.414^{* * *}$ \\
& & & & & $(5.44)$ \\
Size & $0.063^{* * *}$ & $0.169^{* * *}$ & $0.402^{* * *}$ & $0.086^{* * *}$ & $0.090^{* * *}$ & $0.090^{* * *}$ \\
& $(7.34)$ & $(16.65)$ & $(6.67)$ & $(11.88)$ & $(13.56)$ & $(13.53)$ \\
Age & $0.004^{* * *}$ & $0.003^{* * *}$ & 0.001 & -0.001 & -0.000 & -0.000 \\
& $(8.96)$ & $(6.61)$ & $(0.53)$ & $(-1.45)$ & $(-0.96)$ & $(-0.97)$ \\
Productivity & -0.015 & $-0.053^{*}$ & -0.033 & -0.007 & $-0.025^{*}$ & $-0.024^{*}$ \\
& $(-1.24)$ & $(-1.85)$ & $(-0.58)$ & $(-0.64)$ & $(-1.92)$ & $(-1.88)$ \\
Exchange & $0.028^{* * *}$ & $0.052^{* * *}$ & $0.060^{* * *}$ & $0.038^{* * *}$ & $0.024^{* * *}$ & $0.056^{* * *}$ \\
& $(17.11)$ & $(16.10)$ & $(8.33)$ & $(7.34)$ & $(14.41)$ & $(8.62)$ \\
Observations & 15,949 & 29,420 & 29,420 & 21,986 & 29,420 & 29,420 \\
Test of equality & & & & & & \\
\hline Liquidity & 0.000 & 0.002 & 0.007 & 0.098 & 0.008 & 0.000 \\
Leverage & 0.000 & 0.004 & 0.067 & 0.025 & 0.054 & 0.048 \\
\hline
\end{tabular}

Notes: The dependent variable is a dummy equal to one if a firm exits the export market in year $t$, and zero otherwise. Robust z-statistics are presented in the parentheses. * significant at $10 \%$; ** significant at $5 \%$; *** significant at $1 \%$. Time dummies, industry dummies and regional dummies were included in the model. Table presents the p-values of a test for the equality of the coefficients on the interacted terms. Columns 1 presents results for a shorter sample of firms that started exporting for the first time in 2000. In columns 2 the dependent variable is re-defined to include only firms which exit the export market definitely. Columns 3 reports results on the random-effect proportional hazard model. In columns 4 the specification was estimated using instrumental variable technique for probit models. Column 5 reports results based on the 2008-09 crisis period and column 6 includes the crisis dummy on its own and the interactions with leverage and liquidity. Also see notes to Table 1. 
Table 5: Robustness: Borrowing Ratio

\begin{tabular}{|c|c|c|c|c|c|c|}
\hline & $\begin{array}{c}\text { Re-define } \\
\text { sample } \\
(1)\end{array}$ & $\begin{array}{l}\text { Re-define } \\
\text { exiter } \\
(2)\end{array}$ & $\begin{array}{c}\text { xtcloglog } \\
(3) \\
\end{array}$ & $\begin{array}{l}\text { IV } \\
(4) \\
\end{array}$ & $\begin{array}{c}\text { Alternative } \\
\text { crisis } \\
(5)\end{array}$ & $\begin{array}{c}\text { Full effect } \\
\text { of crisis } \\
(6)\end{array}$ \\
\hline Liquidity ${ }^{*}$ Crisis ${ }^{*} H B R$ & $\begin{array}{c}-0.565^{* * *} \\
(-4.18)\end{array}$ & $\begin{array}{c}-1.154^{* * *} \\
(-4.82)\end{array}$ & $\begin{array}{c}-1.900 * * * \\
(-3.65)\end{array}$ & $\begin{array}{c}-1.133^{* * *} \\
(-4.15)\end{array}$ & $\begin{array}{c}-0.658^{* * *} \\
(-4.09)\end{array}$ & $\begin{array}{c}-0.707^{* * *} \\
(-5.41)\end{array}$ \\
\hline Liquidity* $(1-$ Crisis $) * H B R$ & $\begin{array}{c}-0.112^{*} \\
(-1.86)\end{array}$ & $\begin{array}{c}-0.380^{* * *} \\
(-4.82)\end{array}$ & $\begin{array}{c}-0.542^{* *} \\
(-2.06)\end{array}$ & $\begin{array}{c}-0.421^{* *} \\
(-2.11)\end{array}$ & $\begin{array}{c}-0.328^{* * *} \\
(-6.62)\end{array}$ & $\begin{array}{c}-0.306^{* * *} \\
(-6.04)\end{array}$ \\
\hline Liquidity ${ }^{*}$ Crisis $*(1-H B R)$ & $\begin{array}{l}-0.221 \\
(-1.48)\end{array}$ & $\begin{array}{c}-0.624^{* * *} \\
(-3.65)\end{array}$ & $\begin{array}{c}-0.958^{* * *} \\
(-3.64)\end{array}$ & $\begin{array}{c}-0.516^{* *} \\
(-2.36)\end{array}$ & $\begin{array}{c}-0.434^{* * *} \\
(-4.12)\end{array}$ & $\begin{array}{c}-0.455^{* * *} \\
(-5.5)\end{array}$ \\
\hline Liquidity $^{*}(1-C r i s i s) *(1-H B R)$ & $\begin{array}{l}-0.125 \\
(-1.60)\end{array}$ & $\begin{array}{c}-0.359^{* * *} \\
(-3.94)\end{array}$ & $\begin{array}{c}-0.580^{*} \\
(-1.80)\end{array}$ & $\begin{array}{l}-0.141 \\
(-0.92)\end{array}$ & $\begin{array}{c}-0.277^{* * *} \\
(-4.67)\end{array}$ & $\begin{array}{c}-0.244^{* * *} \\
(-3.98)\end{array}$ \\
\hline Leverage ${ }^{*}$ Crisis ${ }^{*} H B R$ & $\begin{array}{l}0.073 \\
(0.70)\end{array}$ & $\begin{array}{c}0.425^{* *} \\
(2.17)\end{array}$ & $\begin{array}{l}0.745 \\
(1.64)\end{array}$ & $\begin{array}{c}0.545^{* * *} \\
(3.01)\end{array}$ & $\begin{array}{c}0.282^{* *} \\
(3.15)\end{array}$ & $\begin{array}{c}0.235^{* *} \\
(3.38)\end{array}$ \\
\hline Leverage $^{*}(1-$ Crisis $){ }^{*} H B R$ & $\begin{array}{l}-0.056 \\
(-1.37)\end{array}$ & $\begin{array}{l}0.009 \\
(0.18)\end{array}$ & $\begin{array}{l}0.253 \\
(1.40)\end{array}$ & $\begin{array}{c}0.254^{* * *} \\
(3.36)\end{array}$ & $\begin{array}{c}0.092^{* * *} \\
(2.80)\end{array}$ & $\begin{array}{c}0.089^{* * *} \\
(2.67)\end{array}$ \\
\hline Leverage ${ }^{*}$ Crisis ${ }^{*}(1-H B R)$ & $\begin{array}{l}-0.054 \\
(-0.34)\end{array}$ & $\begin{array}{l}0.357 \\
(1.33)\end{array}$ & $\begin{array}{l}0.276 \\
(0.39)\end{array}$ & $\begin{array}{l}0.178 \\
(0.31)\end{array}$ & $\begin{array}{l}0.183 \\
(1.00)\end{array}$ & $\begin{array}{l}0.021 \\
(0.14)\end{array}$ \\
\hline Leverage $^{*}(1-$ Crisis $) *(1-H B R)$ & $\begin{array}{l}0.019 \\
(0.26)\end{array}$ & $\begin{array}{c}-0.540^{* * *} \\
(-5.54)\end{array}$ & $\begin{array}{l}-0.073 \\
(-0.25)\end{array}$ & $\begin{array}{l}0.349 \\
(0.52)\end{array}$ & $\begin{array}{c}0.167^{* * *} \\
(2.94)\end{array}$ & $\begin{array}{c}0.161^{* * *} \\
(2.76)\end{array}$ \\
\hline Crisis & & & & & & $\begin{array}{c}1.519^{* * *} \\
(5.52)\end{array}$ \\
\hline Size & $\begin{array}{c}0.059^{* * *} \\
(6.66)\end{array}$ & $\begin{array}{c}0.166^{* * *} \\
(15.85)\end{array}$ & $\begin{array}{c}0.287^{* * *} \\
(5.59)\end{array}$ & $\begin{array}{c}-0.497^{* * *} \\
(-3.02)\end{array}$ & $\begin{array}{c}0.081^{* * *} \\
(11.63)\end{array}$ & $\begin{array}{c}0.081^{* * *} \\
(11.59)\end{array}$ \\
\hline Age & $\begin{array}{c}0.004^{* * *} \\
(8.21)\end{array}$ & $\begin{array}{c}0.004^{* * *} \\
(6.68)\end{array}$ & $\begin{array}{l}-0.000 \\
(-0.14)\end{array}$ & $\begin{array}{c}0.004^{* *} \\
(2.51)\end{array}$ & $\begin{array}{l}-0.001 \\
(-1.63)\end{array}$ & $\begin{array}{l}-0.001 \\
(-1.64)\end{array}$ \\
\hline Productivity & $\begin{array}{l}-0.021 \\
(-1.56)\end{array}$ & $\begin{array}{l}-0.037 \\
(-1.31)\end{array}$ & $\begin{array}{l}-0.027 \\
(-0.47)\end{array}$ & $\begin{array}{c}-0.181^{* * *} \\
(-3.27)\end{array}$ & $\begin{array}{l}-0.019 \\
(-1.38)\end{array}$ & $\begin{array}{l}-0.018 \\
(-1.34)\end{array}$ \\
\hline Exchange & $\begin{array}{c}0.028^{* * *} \\
(16.37)\end{array}$ & $\begin{array}{c}0.051^{* * *} \\
(15.33)\end{array}$ & $\begin{array}{c}0.058^{* * *} \\
(7.72)\end{array}$ & $\begin{array}{c}0.064^{* * *} \\
(7.04)\end{array}$ & $\begin{array}{c}0.024^{* * *} \\
(13.79)\end{array}$ & $\begin{array}{c}0.024^{* * *} \\
(15.00)\end{array}$ \\
\hline Observations & 14,947 & 27,254 & 27,254 & 14,460 & 27,254 & 27,254 \\
\hline $\begin{array}{l}\text { Test of equality } \\
\text { Liquidity } * H B R\end{array}$ & 0.006 & 0.002 & 0.032 & 0.052 & 0.049 & 0.004 \\
\hline Liquidity $*(1-H B R)$ & 0.564 & 0.151 & 0.065 & 0.152 & 0.153 & 0.039 \\
\hline Leverage $* H B R$ & 0.248 & 0.039 & 0.303 & 0.082 & 0.031 & 0.054 \\
\hline Leverage $*(1-H B R)$ & 0.673 & 0.001 & 0.645 & 0.837 & 0.912 & 0.261 \\
\hline Liquidity $*$ Crisis & 0.082 & 0.069 & 0.087 & 0.075 & 0.089 & 0.06 \\
\hline Liquidity $*(1-$ Crisis $)$ & 0.883 & 0.847 & 0.917 & 0.129 & 0.461 & 0.394 \\
\hline Leverage $*$ Crisis & 0.416 & 0.804 & 0.493 & 0.511 & 0.578 & 0.074 \\
\hline Leverage $*(1-$ Crisis $)$ & 0.258 & 0.000 & 0.214 & 0.856 & 0.645 & 0.271 \\
\hline
\end{tabular}

Notes: The dependent variable is a dummy equal to one if a firm exits the export market in year $t$, and zero otherwise. Robust z-statistics are presented in the parentheses. ${ }^{*}$ significant at $10 \% ;{ }^{* *}$ significant at $5 \% ;{ }^{* * *}$ significant at $1 \%$. Time dummies, industry dummies and regional dummies were included in the model. Table presents the p-values of a test for the equality of the coefficients on the interacted terms. Also see notes to Table 1, 3 and 4. 
Table A-1: Detailed Statistics of Size Variables

\begin{tabular}{|c|c|c|c|}
\hline & $\begin{array}{c}\text { UK } \\
\text { Employees } \\
(1)\end{array}$ & $\begin{array}{c}\text { UK } \\
\text { Assets } \\
(2)\end{array}$ & $\begin{array}{c}\text { UK } \\
\text { Turnover } \\
(3)\end{array}$ \\
\hline $25 \%$ & 31 & 2,249 & 4,000 \\
\hline $50 \%$ & 85 & 4,748 & 9,586 \\
\hline $75 \%$ & 234 & 13,932 & 25,442 \\
\hline Observations & 85,231 & 123,535 & 78,760 \\
\hline
\end{tabular}

Notes: The table presents the median and the upper and lower quartiles of three size measures.

Table A-2: Correlation Matrix

\begin{tabular}{lccccccc}
\hline & BR & Leverage & Liquidity & Size & Age & Productivity & Exchange \\
\hline BR & 1.000 & & & & & & \\
Leverage & 0.353 & 1.000 & & & & & \\
Liquidity & -0.265 & -0.377 & 1.000 & & & & \\
Size & 0.056 & 0.074 & 0.013 & 1.000 & & & \\
Age & -0.064 & -0.104 & 0.123 & 0.193 & 1.000 & & \\
Productivity & 0.032 & 0.037 & -0.001 & -0.248 & -0.054 & 1.000 & \\
Exchange & 0.067 & 0.062 & -0.108 & 0.034 & -0.045 & -0.059 & 1.000 \\
\hline
\end{tabular}

Notes: The table presents the correlation coefficients between regressors.

Table A-3: Structure of the unbalanced panel

\begin{tabular}{lccc}
\hline $\begin{array}{l}\text { Number of obs. } \\
\text { per firm }\end{array}$ & Number of firms & Percent & Cumulative \\
\hline 1 & 30 & 0.21 & 0.21 \\
2 & 24 & 0.17 & 0.37 \\
3 & 37 & 0.25 & 0.63 \\
4 & 43 & 0.30 & 0.92 \\
5 & 78 & 0.54 & 1.46 \\
6 & 106 & 0.73 & 2.19 \\
7 & 142 & 0.98 & 3.17 \\
8 & 217 & 1.49 & 4.66 \\
9 & 701 & 4.82 & 9.48 \\
10 & 13,155 & 90.52 & 100.00 \\
\hline Total & 14,533 & 100.00 & \\
\hline
\end{tabular}

